\title{
PREDICTIVE PARAMETERS FUNCTIONING ARTERIOVENOUS FISTULA FOR HEMODIALYSIS IN THE ELDERLY
}

Radojica V. Stolic ${ }^{1}$, Zoran Bukumiric ${ }^{2}$, Ivana R. Matijasevic ${ }^{3}$, Masa D. Jaksic ${ }^{3}$, Milena Jovanovic ${ }^{4}$ and Teodora G. Kostic ${ }^{5}$ ${ }^{1}$ Department of Internal medicine, Faculty of Medical Sciences, University of Kragujevac, Serbia

${ }^{2}$ Institute for Medical Statistics and Informatics, Faculty of Medicine, University of Belgrade, Serbia ${ }^{3}$ Medical faculty Pristina/K.Mitrovica, University of Pristina, Serbia

${ }^{4}$ Clinic of Urology and Nephrology, Clinical Center Kragujevac, Serbia

${ }^{5}$ Faculty of Medical Sciences, University of Kragujevac, Serbia

\section{PREDIKTIVNI PARAMETRI FUNKCIONISANJA ARTERIOVENSKE FISTULE ZA HEMODIJALIZU KOD STARIJIH OSOBA

\section{ABSTRACT}

Elderly patients with end stage kidney disease represent a challenge for surgeons to create a vascular access.

Determine predictive parameters functionality of the arteriovenous fistulas for hemodialysis in the elderly.

The study was organized as a retrospective study at the Center for Dialysis, Clinic for Urology and Nephrology, Clinical Center Kragujevac. The study included patients older than 65 years with arteriovenous fistula thrombosis, in the period of four years, in which there is information on the length of the functioning fistula. The study included 48 patients, mean age $71.3 \pm 5.2$ years, 29 (60\%) men and 19 (40\%) women. The data were analyzed according to gender and demographic structure, type of anastomosis, positioning, length of functioning fistulas, and the lumen diameter of the arteries and veins that are used to create a fistula.

The median length of functioning arteriovenous fistula, based on Kaplan-Meier model, is 16 months (95\% CI 6.925.1). Median functioning for proximaly located fistulas was 24 months (range, 1-259), while median functioning in patient with distally located fistulas was 8 months (range, 1-96). The difference in relation to the positioning of the fistula was statistically significant $(p=0.006)$. In univariate Cox regression model, a statistically significant predictor of the functioning of arteriovenous fistulae is fistula positioning $(B=0.700 ; p=0.022)$.

The predictive parameter of survival of arteriovenous fistulas in elderly is proximally located fistula.

Keywords: old patients, hemodialysis, arteriovenous fistula, duration, functioning

\section{SAŽETAK}

Stariji bolesnici sa terminalnom bubrežnom insuficijencijom predstavljaju izazov za hirurge koji kreiraju vaskularne pristupe. Cilj rada bio je da se utvrde prediktivni parametri funkcionalnosti arteriovenske fistule za hemodijalizu kod starijih osoba.

Istraživanje je organizovano kao retrospektivna studija $u$ Centru za dijalizu Klinike za urologiju i nefrologiju, Kliničkog centra Kragujevac. Analizirani su bolesnici stariji od 65 godine, sa trombozom arteriovenskom fistulom, u periodu od četiri godine, kod kojih postoji podatak o dužini funkcionisanja fistule. U istraživanje je uključeno 48 bolesnika, prosečne sta-

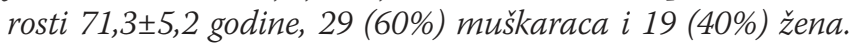
Analizirana je polna i demografska struktura, tip anastomoze, pozicioniranje, dužina funkcionisanja, kao i dijametar lumena arterije $i$ vene koji su korišćeni za kreiranje fistule.

Medijana dužine funkcionisanja arteriovenske fistule, na osnovu Kaplan-Meireovog modela iznosi 16 meseci (95\% Cl 6,9-25,1). Medijana funkcionisanja proksimalno lociranih arteriovenskih fistula iznosila je 24 meseca (opseg, 1-259), dok je kod ispitanika sa distalno lociranim fistulama 8 meseci (opseg, 1-96) a razlika u odnosu na pozicioniranje fistule je statistički značajna ( $p=0,006)$. U univarijantnom Cox-regresionom modelu statistički značajan prediktor dužine funkcionisanja arteriovenske fistule je pozicioniranje fistule $(B=0,700 ; p=0,022)$.

Prediktivni parametar dužine preživljavanja arteriovenske fistule kod starijih osoba je proksimalno locirane fistule.

Ključne reči: stari bolesnici, hemodijaliza, arteriovenska fistula, dužina funkcionisanja

\section{sciendo}

UDK: $616.13 / .14-089.86 ; 616.61-78-053.9$ Ser J Exp Clin Res 2019; 20 (1): 47-51 DOI: 10.1515/SJECR-2017-0021
Corresponding author: Professor Radojica Stolic Faculty of Medical Sciences, Svetozar Markovic 69, 34000 Kragujevac email: radojica.stolic@med.pr.ac.rs; Phone/fax: +38134306800 


\section{INTRODUCTION}

Functional arteriovenous fistula is one of the main factors of survival in hemodialysis patients. There are many parameters that affect the functionality of arteriovenous fistula. A significant increase in the number of elderly patients with end stage kidney disease, points to serious problems in the creation of vascular access. Complications of arteriovenous fistula were significantly more frequent in elderly patients. Important parameters such as life expectancy, price, number of required audits, as well as the duration of hemodialysis should be analyzed in future studies to clarify the best options for a dramatic increase in the elderly population (1).

In the case of the failure arteriovenous fistula, in elderly patients, a better option is to create a new fistula, than to attempt of rescue current fistula. In the current guides there are no specific guidelines for the creation of fistula in the elderly. The relationship between unnecessary and necessary operations in order to create a vascular access has always been higher in the elderly compared to younger patients. Old hemodialysis patients have a shorter life expectancy, $50 \%$ of patients aged 75 years dies in the first year of hemodialysis treatment. Establishing an optimal vascular access in the elderly patients, is a major challenge. Recent studies have shown that two-thirds of older patients, which had fistula created, die before it's use. In patients with glomerular filtration rate less than $15 \mathrm{ml} / \mathrm{min}$ or when the maintenance hemodialysis onset is expected in the next six months, the most rational solution is creation of fistula $(2,3)$.

The procedure of creating vascular access, and expected complications are an important cause of morbidity and mortality in the population of hemodialysis patients. Therefore, the assessment of the older patient, and his or her suitability for the formation of vascular access is of fundamental value, as it represents the key component of the planning process. Fatigue, exhaustion, malnutrition and general frailty is a common feature of older patients. In patients with end stage kidney disease are recorded bath skin and a greater possibility of forming a hematoma. Likewise, the use of anticoagulants can potentially increase the risk of bleeding. Older patients have a higher incidence of peripheral vascular disease, atherosclerosis, hypertension and arterial calcification $(4,5)$.

Help and support in making joint decisions regarding the creation of vascular access will be focused on improving communication, knowledge transfer between patients and doctors, in order to generate information that will allow patients and physicians realistic expectations about the different treatment options.

The purpose of this study was to determine predictive parameters for functionality of the arteriovenous fistulas for hemodialysis in the elderly.

\section{MATERIALS AND METHODS}

The study was designed as retrospective, conducted at the Center for Dialysis, Clinic of Urology and Nephrology,
Clinical Center Kragujevac. We analyzed all patients on hemodialysis, who were older than 65 years, with thrombosis of arteriovenous fistula, where there is information on the length of functioning fistula.

The study included 48 patients, mean age $71.3 \pm 5.2$ years, $29(60 \%)$ men and $19(40 \%)$ women.

\section{Clinical and demographic parameters}

The data were analyzed according to gender and demographic structure, type of anastomosis, positioning and length of functioning fistulas, as well as the diameter of the arteries and veins that are used to create a fistula.

The study was retrospective, conducted at the Center for Dialysis, Clinic of Urology and Nephrology, Clinical Center Kragujevac. We analyzed all patients on hemodialysis, who were older than 65 years, with thrombosis of arteriovenous fistula, where there is information on the length of functioning fistula.

The study included 48 patients, mean age $71.3 \pm 5.2$ years, $29(60 \%)$ men and 19 (40\%) women.

The study was approved by the Ethics committee of the Clinical Center Kragujevac and was performed in accordance with the Helsinki declaration for medical research.

\section{Statistical analysis}

For the analysis of primary data we used descriptive statistical methods, for testing statistical hypotheses and methods for the analysis of time to the occurrence of events of interest. From the descriptive statistical method we used measures of central tendency, measures of variability and relative numbers. For testing statistical hypothesis we used Mann-Whitney test. For an analysis of the duration of the arteriovenous fistula was used Kaplan-Meier method, to find independent predictors of length of the Cox regression model with 95\% confidence interval. The statistical hypotheses were tested for statistical significance level of 0.05 .

\section{RESULTS}

In our study, of the 48 respondents in total, 29 (60\%) patients were men and 19 (40\%) women. Eight patients (17\%) had end-to-end anastomosis, while $40(83 \%)$ had termino-lateral anastomosis. In relation to the positioning of the fistula, $29(60 \%)$ patients had proximal fistula, whereas $19(40 \%)$ patients had a distal fistula. In relation to the placement of central venous catheter $30(62.5 \%)$ of the respondents had a catheter, as a temporary vascular access. The mean value of the vein diameter, in our patients, was $2.5 \pm 0.6 \mathrm{~mm}$, while mean of the artery diameter was $2.7 \pm$ $0.6 \mathrm{~mm}$ (Table 1).

Evaluation of the median duration of arteriovenous fistula, based on Kaplan-Meire model is 16 months (95\% CI 6.9 to 25.1 ), (Figure 1 ). 
Table 1. Clinical characteristics of patients included in the study

\begin{tabular}{lc}
\hline Variables & $\mathrm{n}=48$ \\
\hline Age (years), mean $\pm \mathrm{sd}$ & $71.3 \pm 5.2$ \\
Gender, n(\%) & $29(60 \%)$ \\
men & $19(40 \%)$ \\
women & \\
Type of anastomosis, $\mathrm{n}(\%)$ & $8(16.7 \%)$ \\
termino-terminal & $40(83.3 \%)$ \\
termino-lateral & \\
Location arteriovensous fistula, $\mathrm{n}(\%)$ & $29(60 \%)$ \\
proximal fistula & $19(40 \%)$ \\
distal fistula & $30(62.5 \%)$ \\
Central-venous catheter, $\mathrm{n}(\%)$ & $2.5 \pm 0.6$ \\
Diameter of the vein (mm), mean $\pm \mathrm{sd}$ & $2.7 \pm 0.6$ \\
Artery diameter (mm), mean $\pm \mathrm{sd}$ &
\end{tabular}

Table 2. Correlation lengths functioning of the arteriovenous fistula in relation to the examined clinical variables

\begin{tabular}{lcc}
\hline Variables & Mediana (range) & p-value \\
\hline Gender, n(\%) & $18(1-95)$ & 0.916 \\
men & $16(1-259)$ & \\
women & & \\
Type anastomosis, n(\%) & $15.5(2-56)$ & 0.430 \\
termino-terminal & $17(1-259)$ & \\
termino- lateral & & \\
Central-venous catheter, n(\%) & $21(1-259)$ & 0.749 \\
yes & $15(1-96)$ & \\
no &
\end{tabular}

Table 3. Univariate Cox regression models

\begin{tabular}{lcc}
\hline Predictors & $\begin{array}{c}\text { Hazard ratio } \\
(96 \% \mathrm{CI})\end{array}$ & p-value \\
\hline Age (years) & $1.02(0.97-1.08)$ & 0.387 \\
Gender & $0.73(0.39-1.36)$ & 0.315 \\
Type anastomosis & $0.62(0.28-1.36)$ & 0.233 \\
Location of the arteriovenous fistula & $2.01(1.10-3.67)$ & $0.022^{*}$ \\
Central-venous catheter & $1.02(0.56-1.86)$ & 0.944 \\
Diameter of the vein & $1.46(0.81-2.64)$ & 0.213 \\
Artery diameter & $1.28(0.72-2.28)$ & 0.411 \\
\hline "Statistically significant difference & &
\end{tabular}

"Statistically significant difference

Median functioning of the arteriovenous fistula in men was 18 months (range, 1-95), while in female respondents it was 16 months (range, 1-259), which is not a statistically significant difference $(\mathrm{p}=0.916)$. In relation to the type of the arterio-venous anastomosis, there was no statistically significant difference, compared to the length of the functioning fistula $(\mathrm{p}=0.430)$. There was no statistically significant difference shown in the length of functioning arteriovenous fistula between the patients with and without a central-venous catheter $(\mathrm{p}=0.749)$, (Table 2).

Median functioning for proximally located fistulas was 24 months (range, 1-259), while median functioning in patient with distal located fistulas was 8 months (range, 1-96). The difference in relation to the position-

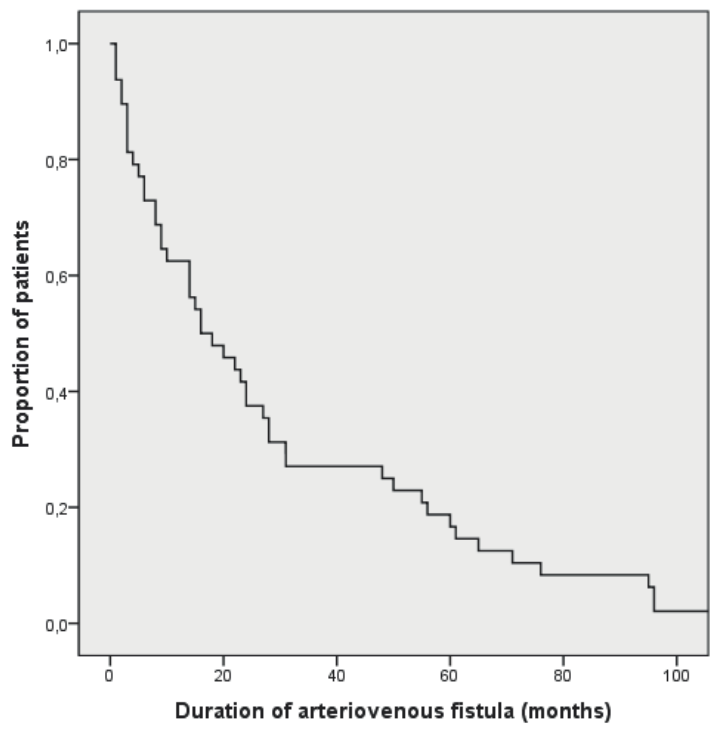

Figure 1. Kaplan-Meire curve proportion of respondents with regard to the functioning of arteriovenous fistula

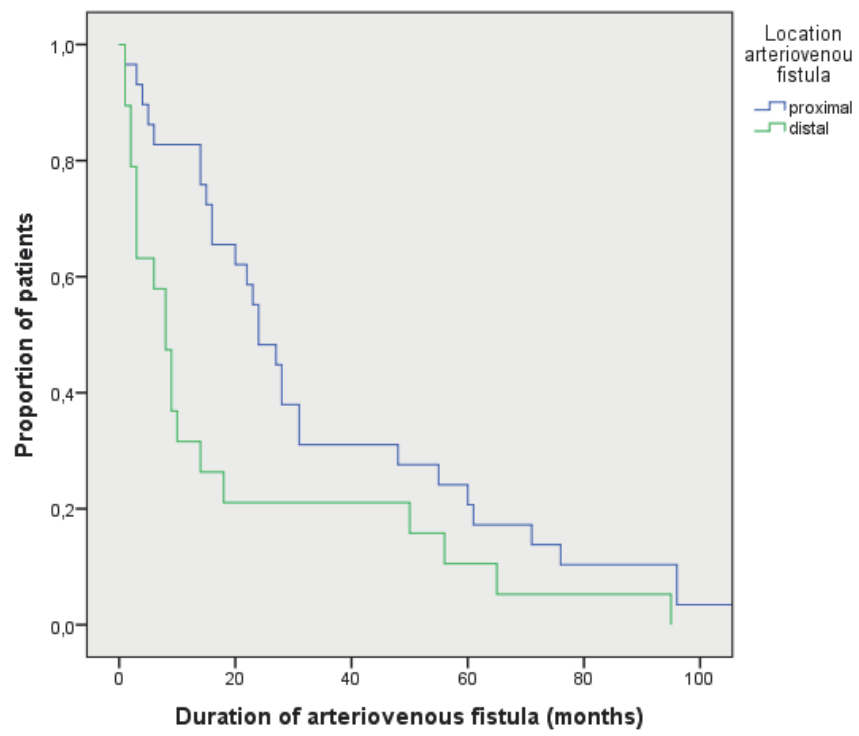

Figure 2. The correlation of the duration in relation to the location of the arteriovenous fistula

ing of the fistula was statistically significant $(\mathrm{p}=$ 0.006). Median functioning arteriovenous fistula in patients with proximal location is 24 months (range, 1-259), while in patients with distal location 8 months (range, 1-95). A statistically significant difference was found in relation to the location of the arteriovenous fistula $(p=0.006)$. Subjects with proximally located fistula had statistically significant longer duration od arteriovenous fistula. Figure 2.

Univariate Cox regression models found that a statistically significant predictor duration is positioning of arteriovenous fistula $(\mathrm{B}=0.700 ; \mathrm{p}=0.022)$, Table 3. 


\section{DISCUSION}

Not so long ago, a contraindication for the initiation of hemodialysis, was patients age over 45 years. Today, however, the number of elderly patients on hemodialysis reaches $25-30 \%$ of the total number of patients with end stage kidney disease $(1,2)$. Number of elderly patients over 75 years seems almost a third of all patients on chronic hemodialysis with a tendency of further growth (6). The mean age of the participants was 71.3 years. Having an insight into its own database (unpublished data), trend can not be established of continuous increasing in elderly, who requested the creation artriovenous fistulas for hemodialysis.

The latest research establishes doubt about previous strategies, when it comes to the type of vascular access in the elderly and advocate for greater flexibility in the choice of the vascular access for hemodialysis. Restriction policy, aimed at optimizing vascular access for hemodialysis has certain omissions, because it does not consider complexity and challenges of the disease, as well as the different experiences and characteristics of individual patients with chronic kidney disease (3). Experience of our center showed that the optimal vascular access is arteriovenous fistula, regardless of age, unless there are significant contraindications.

In accordance with current guide, radiocephalic fistula is a primary choice of the vascular access for hemodialysis. However, this strategy is more frequently contested, especially when it comes to older populations. Due to the significant comorbidity in older patients, such as uremic or ischemic cardiomyopathy, peripheral vascular disease, diabetes mellitus, there is greater doubt in the successful functioning of distal arteriovenous fistula. Preserving the proximal blood vessels, for the purpose of creating a vascular access in the elderly, is of no crucial importance, especially with the position of patients with limited life expectancy. Cubital arteriovenous fistula in elderly hemodialysis patients have greater functionality for the year, compared with radiocephalic fistulas. Such policy can reduce the rate of initial afunction and the need to use temporary central-venous catheters (4). In two-year follow of duration of functioning arteriovenous fistula in elderly patients in our study is 16 months (95 CI 6.9 to 25.1), with no statistical differences in relation to gender, nor in relation to the placement of central-venous catheters. Median functioning of the proximal arteriovenous fistula is 24 months, a distal 8 months. We found that subjects with proximal fistulas have longer duration. Nearly two-thirds of our respondents have proximal location of arteriovenous anastomoses, which is in line with current data $(6,7)$.

On the other hand, permanent central venous catheter hemodialysis patients in the United States is used in over $80 \%$ of patients. It is interesting to notice the results of avaliable studies that, when looking at period less than two years, there is no difference in mortality between patients with permanent central-venous catheters and arteriove- nous fistulas in the elderly (8). The results of our study showed that $62.5 \%$ of respondents had a placed central venous catheter, but only as temporary vascular access.

Central venous catheter is used more frequently in elderly hemodialysis patients in Europe, Australia, North America, but rarely in Japan (2). On the other hand, analysis of hospitalizations between 1995 and 2006 in the United States showed that the lowest number of hospitalized older patients on hemodialysis was conducted because of infection of the vascular access (9).

When it comes to vascular accesses, there are not appropriate recommendations which regards the elderly. Existing guidelines suggest that the choice of distal arteriovenous fistula in elderly is associated with frequent primary afunction. Benefits of radiocephalic fistula, in the event of failure, is that there is a possibility of repeated, proximal attempts. However, only $12 \%$ of elderly patients have a adequate radio-cephalic fistula (4). In our study, 19\% of respondents have a distal fistula, probably because of the policy of our Center that is primarily focused on the creation of native arteriovenous fistula and, wherever possible, distally, regardless of their age.

Stratified studies suggest discordance between clinical practice guidelines for vascular access, and measures of clinical performance, suggesting the need of individual approach in many aspects of care of patients with end stage kidney disease. This could be in conflict with the current clinical practice guidelines. In fact, strict application of these recommendations may be inappropriate for certain patients $(3,10-12)$.

The absence of guidelines related to vascular access for older people, is result of the exclusion of older people from the process of achieving certain guidelines. There is almost declarative consensus that brachiocephalic fistula have significantly higher rate of the duration, compared to radiocephalic fistula $(2,13)$. The results of our studies have found that a statistically significant predictor of the length of the functioning of arteriovenous fistulae in older patients, is proximal positioning of arterio-venous anastomosis $(\mathrm{B}=$ 0.700; $\mathrm{p}=0.022$ ).

Data on the successful creation of functional fistula, in elderly patients, are contradictory, primarily due to noncompliance definitions of age (5). REDUCE-FTM I study (14), in one-year period, showed that elderly patients have $70 \%$ greater chance for a non-functional fistula. In the elderly patients, with end stage kidney disease, due to lower lumen of blood vessels, the higher rate of the initial dysfunction, shorter life expectancy, and a larger number of comorbidities, arteriovenous fistula should not be a universal option for vascular access. It is interesting that today, according to some titles, it seems more and more that the problem of vascular access creation goes beyond the reality of clinical nephrology, and that theology and religion is included in the phenomenology of creating arteriovenous fistula (15).

Elderly patients, during their lives undergo numerous diagnostic and medical procedures, which often require 
numerous venipuncture, which is a proven risk factor for stenosis and consequential dysfunction of arteriovenous fistula $(1,16)$. The current data identifies risk factors (age, diabetes mellitus, smoking, peripheral vascular disease, predialysis hypotension, characteristics of blood vessels, obesity, use of adjuvant therapy) (17), but there is no data on the impact of gender and type of anastomosis, as a predictive parameter functioning arteriovenous fistula, except in terms of increased incidence of steal syndrome in older people with termino-terminal anastomosis (18).

\section{CONCLUSION}

Predictive parameter for duration of arteriovenous fistulas for hemodialysis in patients of older age, in our study, is proximal location of the arteriovenous anastomoses.

\section{ACKNOWLEDGEMENTS}

This research is partly supported by the Ministry of Education and Science of Serbia, Grants III41010.

\section{CONFLICT OF INTEREST}

The authors declare no financial or other conflict of interests regarding this paper.

\section{REFERENCE}

1. Swindlehurst N, Swindlehurst A, Lumgair H et al. Vascular access for hemodialysis in the elderly. J Vasc Surg 2011; 53: 1039-43; DOI: 10.1016/j.jvs.2010.09.068.

2. Moist ML, Lok CE, Vachharajani TJ et al. Optimal Vascular Access in the Elderly Patient. Semin Dial 2012; 25(6): 640-648.

3. O'Hare AM. Vascular Access for Hemodialysis in Older Adults: A "Patient First” Approach. JASN 2013; 24(8): 1187-90.

4. Lazarides MK, Georgiadis GS, Antoniou GA, Staramos DN. A meta-analysis of dialysis access outcome in elderly patients. Journal of Vascular Surgery 2007; 45 (2): 420-6.

5. Lameire N, Van Biesen W. A 'secular' view on vascular access in haemodialysis. Nephrol Dial Transplant 2012; 0: 1-4.

6. Cui J, Steele D, Wenger J et al. Hemodialysis arteriovenous fistula as first option not necessary in elderly pa- tients. J Vasc Surg 2016; 63(5): 1326-32; doi: 10.1016/j. jvs.2015.11.036.

7. Tordoir JH, Bode AS, van Loon MM. Preferred strategy for hemodialysis access creation in elderly patients. Eur J Vasc Endovasc Surg 2015; 49(6): 738-43; doi: 10.1016/j.ejvs.2015.02.006.

8. Murea M, Satko S. Looking Beyond "Fistula First" in the Elderly on Hemodialysis. Semin Dial 2016; 29(5): 396-02; doi: 10.1111/sdi.12481.

9. U.S. Renal Data System 2008: Chapter 6: Morbidity and mortality. In: USRDS 2008 Annual Data Report: Atlas of Chronic Kidney Disease and End-Stage Renal Disease in the United States. Available at http:// www.usrds. org/2008/pdf/V2_06_2008.pdf, accessed May 16, 2015.

10. Lee T, Thamer M, Zhang Y, Zhang Q, Allon M. Outcomes of Elderly Patients after Predialysis Vascular Access Creation. J Am Soc Nephrol 2015; 26(12): 3133-40; doi: 10.1681/ASN.2014090938.

11. Franco MR, Fernandes NM. Dialysis in the elderly patient: a challenge of the XXI century--narrative review. J Bras Nefrol 2013; 35(2): 132-41; doi: 10.5935/01012800.20130022.

12. Lameire N, Van Biesen W. Moderator's view: a 'secular' view on vascular access in haemodialysis. Nephrol Dial Transplant 2012; 27(10): 3758-61; doi: 10.1093/ndt/gfs275.

13. Fila $B$, Magaš $S$, Pavić $P$, Ivanac R, Ajduk $M$, Malovrh $M$. The importance of success prediction in angioaccess surgery. Int Urol Nephrol 2016; 48(9): 1469-75; doi: 10.1007/s11255-016-1318-8.

14. Lok CE, Allon M, Moist L, Oliver MJ, Shah H, Zimmerman D. Risk equation determining unsuccessful cannulation events and failure to maturation in arteriovenous fistulas (REDUCE FTM I). J Am Soc Nephrol 2006; 17: 3204-12.

15. Basile C, Lomonte C. Pro: the arteriovenous fistula is a blessing of God. Nephrol Dial Transplant 2012; 27(10): 3752-6; doi: 10.1093/ndt/gfs085.

16. Bashar K, Zafar A, Elsheikh S et al. Predictive parameters of arteriovenous fistula functional maturation in a population of patients with end-stage renal disease. PLoS One. 2015 Mar 13;10(3):e0119958. doi: 10.1371/ journal.pone.0119958.

17. Smith GE, Gohil R, Chetter IC. Factors affecting the patency of arteriovenous fistulas for dialysis access. J Vasc Surg 2012; 55(3): 849-55; doi: 10.1016/j.jvs.2011.07.095.

18. Stolic R. Most important chronic complications of arteriovenous fistulas for hemodialysis. Med Princ Pract 2013; 22(3): 220-8; doi: 10.1159/000343669. 